\title{
From Landscape to Cityscape: Recent Interdisciplinary Work
}

\section{David E. Nye}

Odense University

No one who has observed the development of American cities in recent decades can ignore several long-term trends. The population density continues to decline, suburbia (and beyond it exurbia) continues to grow, reliance on the automobile increases, and commerce follows and fosters these trends, as malls, office towers, and corporations move into the hinterland. Americans seem intent on abandoning the European form of the city, even if there are some rear-guard actions such as gentrification that seek to reclaim old neighborhoods. Surely it is not coincidental that in the same years studies of landscape have become more important within disciplines at the heart of any definition of American studies, notably literalure, history, and sociology. All three have expanded upon the traditional concerns of art history and geography. One result of this proliferation of work on landscape is a certain instability in the meaning of the term itself, an instability that a short review essay cannot hope to resolve. Instead, I will provide a guide to recent work, providing a sense of the various current approaches to landscape and cityscape. Certainly one can say that notions of landscape as nature are seldom advanced any more. Authors seem to recognize that every landscape is a social construction. The word "landscape" increasingly is being used not in the conventional sense of the term, as an attractive view that can be taken in at a glance. Rather, as J. B. Jackson has argued, the word "landscape" has greater implications. All landscapes are partially shaped by people, and while it might seem that this generalization is far less true in such places as Utah, Nevada, and Arizona than in Connecticut or Florida, even these 
landscapes are socially constructed in several senses. First, as Jackson emphasizes, people always have left their mark on the land, both intentionally and inadvertently. Native Americans have hunted and farmed there for millennia. White Americans have constructed mines, roads, towns, dams, and irrigation canals that have changed the appearance of the land. Second, landscape views of the West are socially constructed. The visual conventions we use to understand it emerged from painting and photography and were made universal by advertising and film. The tourist arrives with preconceptions. There is no innocent eye looking at today's West. Even if a landscape be regarded primarily as an unspoiled natural view, it is always seen through the lens of a powerful visual culture.

Furthermore, as Jackson argues, landscape refers to more than a view. The word "landscape" is also a verb, referring to the active process of changing the appearance of the world, and this landscaping occurs incessantly, though hardly as a meticulously planned activity. The result is a concatenation of many choices, ranging from state laws to the decorative whims of property owners who introduce new plants into a region. This review will rely on Jackson's definition of landscape: "A composition of man-made or man-modified spaces to serve as infrastructure or background for our collective existence." Landscape is thus not defined as natural but cultural. It is not merely something seen, rather it is part of the essential infrastructure of our existence. Landscape is a shared creation and a collective responsibility.

Such a definition lends itself not only to studies of the countryside but also to studies of urban space, and this moral conception of landscape is at the heart of several recent books. One is the collection of articles edited by Michael Sorkin, Variations on a Theme Park: The New American City and the End of Public Space. ${ }^{2}$ These eight essays focus primarily on Southern California and to a lesser extent New York. All focus on commodity capitalism in contemporary America, and I cannot recommend too,strongly Margaret Crawford's contribution, "The World in a Shopping Mall" which is both a phenomenological description of the

1 J. B. Jackson, Discovering the Vernacular Landscape (New Haven: Yale University Press, 1984), 8.

2 Michael Sorkin, ed., Variations on a Theme Park: The New American City and the End of Public Space (New York: Noonday, 1992). 
world's largest mall, in West Edmonton, Canada, and a capsule history of malls and their relation to other post-modern spaces such as Disneyland. Mike Davis is also good on "The Militarization of Urban Space" in Los Angeles. ${ }^{3}$ Edward W. Soja surveys Orange County, with its "gated communities," corporate parks, military installations, malls, and universities, "where everything is possible and nothing is real" as symptomatic of the "erosive post-modern geographies...being invented at a furious pace in every urban region of the country." (121)

Their work should ideally be read together with Sharon Zukin's Landscapes of Power. ${ }^{4}$ Given her interest in the subjective experience of space, Zukin devotes an introductory chapter to "The Inner Landscape" in the novels of John Updike, Don DeLillo, and Robert Ward. At the heart of her work are five case studies, starting with two old-style blue-collar communities: a steel town in West Virginia and Detroit. These sites are each attempting to move beyond their heavy-industrial heritage, through the inseparable processes of deindustrialization and gentrification. She next considers Westchester County as a suburb in the age of high-tech and light industry, as it is redefined as a center for corporate headquarters, and then takes on the redefinition of downtowns (notably Manhattan). Last, she devotes a chapter on Disneyland. A sociologist, Zukin always keeps class-relations in mind, and her book is informed by a wide range of perspectives, including the work of Lewis Mumford, David Harvey, and Fredric Jameson. She primarily is concerned both with how "circuits of capital are formed in real spaces" but she also realizes the need to understand the psychological and moral meaning of these reconfigurations of space. Appropriating anthropologist Victor Turner's concept of liminality, she defines the liminal spaces of modern society as "no-man's-land" that is "not easily understood without a guide." Yet at the same time, she sees "lirninality" as "the process by which a landscape of power gradually displaces the vernacular." (269) Notice that, as often happens in sociology, an abstract noun becomes an actor: a "landscape of power" is actively displacing another abstraction.

3 For the full treatment, see Mike Davis, City of Qunrtz: Excavatirzg the Future in Los Angeles (New York: Vintage, 1992).

4 Sharon Zukin, Landscapes of Power: From Detroit to Disney World (Berkeley: University of California Press, 1991). 
Turner developed the concept of liminality in order to understand rituals in African tribes. Oversimplifying his theory, in a liminal state the hierarchical order of society temporarily breaks down, people merge briefly into an undifferentiated mass, and emerge renewed from the experience. He saw liminality as part of the anti-structure societies require to counterbalance their structures. In Zukin and other contemporary writers, however, liminality ceases to be rooted in specific practices or theories of social structure, and instead becomes a term to describe spaces which are uncomfortable or ambiguous: "liminal spaces cross and combine the influence of major institutions: public and private, culture and economy, market and place." (269)

In contrast to Sorkin and Zultin, who are critical of the malling of America and the dissolution of older spatial forms, John M. Findlay takes a more positive attitude toward many of the same phenomena in Magic Lands: Western Cityscapes and American Culture after 1940.5 To his credit, he is less sweeping in his praise than Joel Garreau, who celebrated the new mall-office building complexes as an emerging urban form and baptised it Edge City. ${ }^{6}$ For Findlay, Disneyland, the Seattle World's Fair, the Stanford Research Park, and Sun City, Arizona, together represent a distinctive West Coast approach to urban planning. These "magic lands," like Disney's "magic ltingdom" are legible forms. Each "became a fixture in an ever-changing scene for an ever-changing population." They assumed a prominent place on "people's mental maps of the urban West," and "they brought a measure of refinement by establishing high standards of design, by facilitating development of the arts, and by encouraging new forms of entertainment and amusement."(297) The very spaces that Zukin feels create disorientation and placelessness as they dislodge vernacular forms, in Findlay provide a sharper sense of urban identity. He concludes by contrasting the urban sprawl of Los Angeles with the orderly, controlled "integrity" of "magic lands." "Few people may have wanted their community to become another Los Angeles, but most did not seem to mind having something like another Disneyland in their midst." (303) Clearly Findlay does not share Zukin's unhappiness with

5 John M. Findlay, Magic Lands: Western Cityscapes and American Culture after 1940 (Berkeley: University of California, 1992)

6 Joel Garreau, Edge City: Life on the New Urban Frontier (New York: Doubleday, 1991). 
the large-scale mobilization of capital to create new urban geographies. She stands outside the new space, acutely aware of who is excluded; he is positioned inside, equally aware of the advantages it can confer.

Outside sociology and urban studies the term landscape also is used by cultural historians, particularly when spealting of an urban site which has acquired layers of meanings and become multidimensional. William R. Taylor's selection of sixteen essays, Inventing Times Square, exemplifies this approach, with as many authors exploring Times Square as real estate, tourist site, advertising location, hub of the theater, entertainment center, and sexual netherworld. ${ }^{7}$ What emerges is not only a description of a physical space, but a rich overlay of images and associations, including the songs of Irving Berlin and the Ziegfeld Follies. In such an approach, Times Square emerges as another kind of landscape: overcoded, richly ambiguous, a product of memory, music, and reverie as much as it is a creation of capitalism.

Those working in historical geography have not always welcomed new uses of their terminology. One of the most prominent figures in this field, John Stilgoe, recently wrote that "landscape is not cityscape, but essentially rural, essentially the product of tradition." occurs in his essay on landscape and memory in a fine collection of 19 articles, divided into four groupings: beginnings, landscape as history, landscape as myth and memory, and landscape as art. Cities are scarcely discussed, and the emphasis falls on the relations between aesthetics and ecology, as authors in many cases describe the landscapes of home. These writers are seldom as alienated from the worlds they describe as are the sociologists. Leslie Marmon Silko writes of Pueblo interior and exterior landscapes, for example, and Calvin Stillman begins his essay on ('Learning from Landscape and Nature" by declaring: "I can discuss 'landscape' only in terms of my own reactions to those I have seen and experienced, either in a particular place or in reproduction. . . . Great landscapes always involve a personal response." "Throughout the volume

7 William R. Taylor, Inventing Times Square: Commerce and Culture at the Crossroads of the World (Baltimore: Johns Hopkins University Press, 1996, paperback reprint of Russell Sage Foundation hardcover, 1991).

8 John Stilgoe, "Boyhood Landscape and Repetition," in George F. Thompson, ed, Landscape in America (Austin: University of Texas, 1995), 194.

9 Calvin W. Stillman, "Learning from Landscape and Nature," in Thompson, 51. 
the authors emphasize their engagement with specific places, primarily in phenomenological terms, and nature is understood as an essential, emotional support.

Yet another approach to landscape is to isolate a single feature and examine its historical development. Virgina Scott Jenkins's The Lawn: A History of an American Obsession traces one human compulsion to control nature in the pursuit of social status. ${ }^{10}$ In the sixteenth century "lawn" meant a glade in the forest; in the following century it meant an area that was not being tilled and that was covered with grass. Before the Civil War few Americans had lawns, as homes were built close to the street, often with a small garden in front. A grassy yard gradually emerged as an ideal, encouraged by Andrew Jackson Downing, the ubiquitous Frederick Law Olmstead, a growing number of garden societies, and eventually the City Beautiful Movement. Various government agencies and experimental stations also encouraged the improvement of lawns, which only were assumed to be the norm in the twentieth century. Thus the manicured green carpet that now seems "natural" in American suburbs - a cultural construction that literally costs billions of dollars each year to seed, fertilize, mow, and treat with various chemicals - is a recent invention. It entered national consciousness at about the same time as New York's Central Park was being authorized in $1853^{11}$ and grew into an expected ideal just when parks such as Yosemite were being set aside by Congress. ${ }^{12}$

No doubt in part because I am a cultural historian, such contributions to the literature seem more useful and of more lasting importance than many works on the contemporary scene. Whatever truth there may be to this as a general proposition, certainly Mona Domosh's Invented Cities: The Creation of Landscape in Nineteenth Century New York and Boston will be rewarding to anyone curious about how New Yorkers created their retail district; how the skyscraper city emerged on Manhattan; the

10 Virginia Scott Jenkins, The Lawn: A History of an American Obsession (Washington: Smithsonian, 1994).

11 J. B. Jackson has an elegant short essay worth reading in this context, "The Past and Present Park," in $A$ Sense of Place, A Sense of Time (New Haven: Yale University Press, 1994) 105-119.

12 For a case study see Stanford E. Demars, The Tourist in Yosemite, 1855-1985 (Salt Lake City: University of Utah Press, 1991). 
dynamics of capital and class which led to the development of Boston's Back Bay area, and similar topics. ${ }^{13}$ Domosh is acutely aware that while economic analysis of urban change and its effect on class and gender are important, operating at too high a level of abstraction "does little to explain how those transformations were translated into action in specific circumstances. New Yorlc and Boston took different trajectories in the nineteenth century" creating urban landscapes that were markedly different. Domosh's extensively illustrated study reminds us that capitalism does not work the same way in all places and that local factors, notably the values of elites and the need of particular groups for cultural legitimacy, are crucial in determining the shape of the built environment. 